\title{
Anti-Candida Activity of Essential Oils from Eucalyptus species. A Preliminary Study
}

\author{
Janaina Priscila Barbosa*, Thaís Rossini de Oliveira, Daniele de Godoy Penteado Bragado Puppin, Anderson \\ Laerte Teixeira, Giovana Cláudia Boni, Simone Nataly Busato de Feiria and José Francisco Höfling \\ Department of Oral Diagnosis, State University of Campinas, Brazil
}

Submission: January 05, 2018; Published: April 19, 2018

*Corresponding author: Janaina Priscila Barbosa, Department of Oral Diagnosis, University of Campinas, Brazil, Tel/Fax: +55(19)2106-5322;

Email: janaina.priscila@hotmail.com

\begin{abstract}
Members of the genus Eucalyptus belonging to the Myrtaceae family originate in Australia but have been naturalized on most continents. They are popularly used as an anesthetic, expectorant, anti-inflammatory and antiseptic, because they present antibacterial, antifungal, antiinflammatory and analgesic properties through their essential oils. Faced with the increase resistance of microorganisms to antimicrobials has increased the studies of medicinal plants as an alternative agent for treatments and prevention of infections. Candidiasis is an infection caused by Candida spp. Some strains are already reported as resistant to traditional therapies. Therefore, the present study evaluated the antifungal activity of two species of Eucalyptus spp. through the microdilution method in broth determining the MIC (Minimum Inhibitory Concentration) and determining the CFM (Minimum Fungicidal Concentration). The essential oils of Eucalyptus citriodora and Eucalyptus globulus are biologically active against Candida spp. tested, exhibiting promising antifungal properties and can be used in combination with other traditional antimitotics. Keywords: Eucalyptus spp; Essential oil; Antifungal; Candida spp
\end{abstract}

\section{Introduction}

The use of medicinal plants is an age-old practice where man sought use natural resources to improve their health. The beginning of the use of plants as a resource for the treatment of diseases was empirical, with a view that plants could be an alternative against the cure of diseases [1].

This practice has grown significantly throughout the world in recent years. Some factors favored the increase of its use, such as the option of natural therapies and a greater interest as an alternative of anti-microorganisms. The erroneous belief that natural products are superior to conventional drugs without causing harm to health, associated to the no satisfaction with pharmaceuticals results and self-medication [2], has led researches to work in the scientific search and validation of medicinal plants in the development of new medicinal products or therapeutic combinations due to the resistance of antimicrobial drugs already in use [3,4]. Antimicrobial resistance is reported as one of the greatest threats to human health [5]. This alarming growth of multi resistant bacterial infections due to the excessive use of antimicrobials spectrum has been a factor that has favored the dissemination, mainly of microorganisms of the genus Candida, increasing their chances of causing diseases [6].

The incidence of Candida strains spp. resistance to antifungal treatment has increased in the last decades, being a concern for professionals of health [6]. The most commonly used antifungal for the treatment of candidoses belong to the azoles family (fluconazole, ketoconazole and itraconazole), and polyenes (nystatin and amphotericin B). Excessive use of these drugs is one of the factors that may favor the development of resistant strains to antifungals [7]. Candidiasis is a most commonly diseases caused by Candida albicans species. These infections are of broad spectrum and affect mainly immunodepressed patients, HIVpositive, cancer patients, patients who make excessive use of antibiotics and those who use immunosupressors therapies as in the case of transplants [8].

C. albicans is a pleomorphic fungus, presenting in the yeast form, or as filamentous with the production of hyphae. Such morphological transition capacity is known as polymorphism due to the formation of germ tubes and the consequent development of this form is considered a virulence factor of this specie, which also has the capacity of chlamydospores formation. The two forms are related to the infectious process, and the yeast form has a greater ability to human dissemination while the hyphae have the ability to invade tissues of the host phagocytic cells $[9,10]$.

Resistance to antifungals treatment has becoming a serious public health problem, which justifies the search for new alternatives with antifungal potential [11], and through numerous plant efficiency and reliability as new drugs [12]. 
The members of the genus Eucalyptus, belonging to the Myrtaceae family is originated from Australia, but has been found on most continents. The Eucalyptus is popularly used as anesthetic, expectorant, anti-inflammatory and antiseptic [13]. They are known in medicine as antibacterial, antifungal and having inflammatoy activities, beside analgesic properties through their essential oils. Essential oils from members of the genus Eucalyptus are also used in the pharmaceutical and cosmetics industries due to their biological activities [14].

In view of the increase in antimicrobial resistance cases, studies looking for new drugs to treat infections having medicinal plants as coadjuvants or a promising source for new treatment has been an alternative of research. The objective of this study was to preliminary evaluate the antifungal activity of Eucalyptus spp essential oils against Candida yeasts using the microdilution method (MIC), minimal inhibitory concentration in broth M27-A3 [15], and the determination of the MFC (Minimum Fungicidal Concentration).

\section{Materials and Methods}

\section{Essential oils}

The essential oils of Eucalyptus citriodora (Lot: C064/16) and Eucalyptus globules (Lot: L173) were purchased commercially from the company TERRA FLOR.

\section{Yeast Samples}

Reference strains: Candida rugosa (IZ 12), Candida lusitaniae (IZ 06), Candida glabrata (IZ 07), Candida utilis (CBS 5609), Candida krusei (CBS 573), Candida guilliermondii (CBS 566), Candida tropicalis (CBS 94), Candida albicans (CBS 562), Candida parapsilosis (CBS 604), Candida albicans (ATCC 90028), Candida albicans (ATCC MYA-2876), Candida glabrata (ATCC 5207) Candida parapsilosis (ATCC 22019), Candida lusitaniae (ATCC 200950), Candida tropicalis (ATCC 750). (CBS - Centraalbureau voor Schimmelcultures; IZ -Instituto Zimotécnico - ESALQ/USP; ATCC -The Global Bioresource Center).

\section{Antifungal activity of essential oils. Minimum Inhibitory Concentration (MIC)}

Samples of the essential oils were tested for their activity on Candida spp strains determining the Minimum Inhibitory Concentration (MIC) following the recommendations of the M27-A3 protocol [15].

Inoculum Adjustment: It was prepared in saline solution, equivalent to $5.0 \times 10^{6} \mathrm{CFU} / \mathrm{mL}$ in spectrophotometer. The inoculum was standardized at $2.5 \times 10^{3}$ by serial dilution. In a sterile microplate, $100 \mu \mathrm{l}$ of RPMI was distributed in all wells, the first column added $100 \mu \mathrm{l}$ of the essential oil at the initial concentration, and then the serial microdilution of the essential oils was carried out. After the dilution process was added $100 \mu \mathrm{l}$ of the adjusted inoculum, giving the following groups:

a) Positive control group: culture medium and inoculum, for observation of yeast growth) b) Negative control group 1: culture medium only, for observation possible contamination

c) Negative control group 2: culture medium, essential oil and diluent, the purpose of observing possible contaminations in the microdilution)

d) Negative control group 3: culture medium and diluent, for the purpose to observe possible toxic effects of the diluent on the yeast

e) Test group: Eucalyptus citriodora essential oil (Concentration initial $16 \mathrm{mg} / \mathrm{mL}$ ), or Eucalyptus globulus essential oil $(16 \mathrm{mg} / \mathrm{ml}$ initial concentration) or antifungal treatment commercial Fluconazole (initial concentration $64 \mu \mathrm{g} / \mathrm{ml}$ ) or Amphotericin B (Initial concentration $16 \mu \mathrm{g} / \mathrm{ml}$ ).

The plates were incubated for 24 hours at $37^{\circ} \mathrm{C}$ in an aerobiose oven, and visual reading was performed [15]. The tests were performed in triplicate.

\section{Determination of minimum fungicidal concentration - MFC}

The determination of the Minimum Fungicidal Concentration (MFC) was made in Sabouraud Dextrose Agar plates - SDA (KASVI). The 96 wells were homogenized by pipetting, and an aliquot of $10 \mu \mathrm{l}$ was transferred to the Petri dish. After incubation at $37^{\circ} \mathrm{C}$ for $48 \mathrm{~h}$, the lowest fungicidal concentration was established. MFC was determined as the lowest concentration of essential oils, which does not allow the growth of any fungal colony in solid culture through visual reading to confirm the fungicidal and fungistatic effects of the essential oils tested [16]. The assays were performed in triplicate.

\section{Results}

\section{MIC of Candida spp}

The essential oils were tested against Candida reference strains in order to determine their inhibitory effect through broth microdilution technique. Both oils tested showed inhibitory activity on the planktonic cells of Candida spp (Table 1).

Inhibitory activities of up to $8 \mathrm{mg} / \mathrm{mL}$ were detected, and inhibitory concentrations ranged from $0.5 \mathrm{mg} / \mathrm{ml}$ and $0.125 \mathrm{mg} /$ $\mathrm{ml}$ for Eucalyptus citriodora essential oil and $8 \mathrm{mg} / \mathrm{ml}$ to $1 \mathrm{mg} / \mathrm{ml}$ for essential oil of Eucalyptus globulus.

Fluconazole and amphotericin B antifungal agents were also tested against Candida spp. in order to determine the minimum inhibitory concentration through broth microdilution technique. Fluconazole showed lower inhibitory activity when compared to the antifungal Amphotericin B, which demonstrated inhibitory activity at concentrations between $0.25 \mu \mathrm{g} / \mathrm{ml}$ and $1 \mu \mathrm{g} / \mathrm{ml}$ (Table 1).

After determining the MIC values of the essential oils, an aliquot of the susceptibility assay was used to determine the Minimum Fungicidal Concentration (MFC) against the strains of Candida spp. The essential oil of E. citriodora demonstrated 
fungicidal activity, varying its effect at concentrations between $0.25 \mathrm{mg} / \mathrm{mL}$ and $0.5 \mathrm{mg} / \mathrm{mL}$. The E. globulus essential oil showed fungicidal activity at concentrations of $8 \mathrm{mg} / \mathrm{mL}$ and $1 \mathrm{mg} / \mathrm{ml}$ (Table 1).

\section{Discussion}

In recent years, treatment against candidias is remains a concern due to toxicity and the development of resistance to commercial antifungal agents [17]. The secondary metabolism of plants promotes the production of active compounds that are involved in their defense system. These metabolites are extracted in different ways and different parts of the plant, but mainly make up the essential oils and extracts produced with different vehicles.

The genus Eucalyptus was cultivated and exploited on a large scale for many years. Several species of the genus are used in folk medicine as an antiseptic and for infections treatments of the upper respiratory tract. The essential oils extracted from the leaf of this plant exhibit various biological effects as antibacterial, antifungal and antioxidant activity. The antimicrobial, analgesic and anti-inflammatory properties of E. citriodora and E. globulus species have been reported [18].

In the present study, the data presented through the microdilution method [15] showed antifungal activity of the oils tested against planktonic cells of Candida spp. For E. citriodora essential oil, MIC concentrations ranged from $0.5 \mathrm{mg} / \mathrm{mL}$ to $0.125 \mathrm{mg} / \mathrm{mL}$ among the strains tested. E. globulus oil showed MIC from $2 \mathrm{mg} / \mathrm{mL}$ to $1 \mathrm{mg} / \mathrm{mL}$ for the strains tested, except for the Candida rugosa strain IZ 12, which had its inhibited growth only at $8 \mathrm{mg} / \mathrm{mL}$ concentration (Table 1 ).

The minimal fungicidal concentration (MFC) of E. citriodora essential oil in the Candida strains tested was between 0.25 $\mathrm{mg} / \mathrm{ml}$ and $0.5 \mathrm{mg} / \mathrm{ml}$. The E. globulus essential oil had MFC concentrations between $1 \mathrm{mg} / \mathrm{mL}$ and $8 \mathrm{mg} / \mathrm{mL}$ (Table 1).

Table 1: Visual reading results of Candida spp. (MIC).

\begin{tabular}{|c|c|c|c|c|c|c|}
\hline \multirow{2}{*}{ Reference strains } & \multicolumn{2}{|c|}{ E. citriodora } & \multicolumn{2}{|c|}{ E. globulus } & \multirow{2}{*}{$\begin{array}{c}\text { Fluconazole } \\
\text { MIC }\end{array}$} & \multirow{2}{*}{$\begin{array}{c}\text { Amphotericin B } \\
\text { MIC }\end{array}$} \\
\hline & MIC & MFC & MIC & MFC & & \\
\hline C. albicans ATCC 90028 & 0,25 & 0,25 & 2 & 2 & 1 & 1 \\
\hline C. lusitaniae IZ 06 & 0,25 & 0,25 & 2 & 2 & 1 & 0,5 \\
\hline C. parapsilosis CBS 5604 & 0,125 & 0,25 & 1 & 4 & 2 & 0,25 \\
\hline C. rugosa IZ 12 & 0,25 & 0,5 & 8 & 8 & 1 & 0,25 \\
\hline C. glabrata ATCC 5207 & 0,25 & 0,5 & 1 & 2 & 8 & 0,25 \\
\hline C. guilliermondii CBS 566 & 0,125 & 0,125 & 1 & 1 & 1 & 0,25 \\
\hline C. albicans CBS 562 & 0,25 & 0,25 & 4 & 4 & 1 & 0,25 \\
\hline C. krusei CBS 573 & 0,125 & 0,25 & 2 & 2 & 8 & 0,25 \\
\hline C. tropicalis CBS 94 & 0,5 & 0,5 & 4 & 4 & 2 & 0,25 \\
\hline C. glabrata IZ 07 & 0,25 & 0,25 & 1 & 2 & 8 & 0,25 \\
\hline C. utilis CBS 5609 & 0,125 & 0,125 & 1 & 1 & 4 & 0,25 \\
\hline C. parapsilosis ATCC 22019 & 0,25 & 0,25 & 2 & 2 & 1 & 0,25 \\
\hline C. lusitaniae ATCC 200950 & 0,25 & 0,5 & 4 & 4 & 1 & 1 \\
\hline C. tropicalis ATCC 40281 & 0,25 & 0,5 & 1 & 1 & 1 & 0,25 \\
\hline C. albicans ATCC MYA 2876 & 0,25 & 0,25 & 2 & 2 & 1 & 0,25 \\
\hline C. krusei CBS 6258 & 0,25 & 0,25 & 2 & 4 & 32 & 0,25 \\
\hline
\end{tabular}

These data corroborate with the literature indicating that Eucalyptus species show antimicrobial activity by the presence of bioactive compounds in their essential oil (Luqman et al) [18]. According to Tyagi et al. [19] E. globulus oil showed antimicrobial activity against B. subtillis and S. aureus. E. globulus oil also showed activity against yeast cells, inhibiting the growth of Candida albicans and Saccharomyces cerevisiae. Antibacterial activity against the species Fusobacterium nucleatum and Porphyromonas gingivalis were also observed by Harkat-Madouri et al. [20]. In a study by Dhakad et al. [21], E. globulus exhibited antibacterial and antifungal activity. E. citriodora essential oil has also demonstrated antifungal activity against filamentous fungi species [22]. Luqman et al. [18] also reported the antimicrobial activity of E. citriodora against Candida albicans, Aspergillus flavus and Aspergillus niger, and against the bacterial strains of Escherichia coli and Mycobacterium smegmatis. In addition, oil from E. citriodora exhibited antifungal activity against the dermatophytes Microsporum canis, Trichophyton rubrum and Trichophyton mentagrophytes [23].

All these data, when analyzed together, show that Eucalyptus spp species are potentially antibacterial and antifungal species, exhibiting action against these microorganisms in different ways. Different methodologies of extraction from different parts of the plants can exhibit different bio components with various capacity of microorganism's inhibition suggesting that more researches to look for understand such phenomena must be taken in account. 


\section{Advances in Dentistry \& Oral Health}

Since there are several reports in the literature indicating the antimicrobial action of these plant species, the phenomena of microbial resistance to commercial antifungal, and a smaller possibility to synthesizing new drugs, together with the increase of infections by these microorganisms, justify more extensive studies in the attempt to evaluate the antifungal potential of essential oils using lower concentrations in the synergistic combination with conventional drugs in an attempt to decrease or avoid side effects of these drugs, potentializing their antifungal activity, should be carried out as part of our future researchs, added of citoxicity and anti-cancer tests of such bio-activity plant components, including other parts of these plants.

This research refers to a preliminary study about antifungal potential of the Eucalyptus spp. essential oils against the Candida genus. New investigations as to evaluate the effect of the essential oils of the biofilm of Candida albicans; to evaluate the effect of essential oils on Candida albicans biofilm through Scanning Electron Microscopy; to evaluate the possible cytotoxic effect of essential oils on epithelial cells of the HaCat strain and also to evaluate the possible cytotoxic effect of essential oils "in vivo" in Galleria mellonella larvae are being carried out in an attempt to amplify the knowledge about this plants and its antifungal potential.

\section{Conclusion}

a) The essential oil (EO) from Eucalyptus citriodora and Eucalyptus globulus leaves are biologically active in a dose dependent manner against Candida spp. tested in planktonic cells.

b) The EO from both Eucalyptus species show fungicidal dose dependent activity against yeasts.

\section{References}

1. Petrovska BB (2012) Historical review of medicinal plants' sage. Pharmacogn Rev 6 (11): 1-5.

2. Ekor M (2014) The growing use of herbal medicines: issues relating to adverse reactions and challenges in monitoring safety. Front Pharmacol 4: 177.

3. Nijmoh DL, Assob JC, Mokake SE, Nyhalah DJ, Yinda CK, et al. (2015) Antimicrobial Activities of a Plethora of Medicinal Plant Extracts and Hydrolates against Human Pathogens and Their Potential to Reverse Antibiotic Resistance. Int J Microbiol 2015: 547156.

4. Delaviz H, Mohammadi J, Ghalamfarsa G, Mohammadi B, Farhadi N (2017) A Review Study on Phytochemistry and Pharmacology Applications of Juglans Regia Plant. Pharmacogn Rev 11(22): 145-152.

5. Blair JM, Webber MA, Baylay AJ, Ogbolu DO, Piddock LJ (2015) Molecular mechanisms of antibiotic resistance. Nat Rev Microbio 13(1): 42-51.

6. Bhattacharjee P (2016) Epidemiology and antifungal susceptibility of Candida species in a tertiary care hospital, Kolkata, India. Curr Med Mycol 2(2): 20-27.

7. Menezes RP (2014) Avaliação da freqüência, atividade enzimática e sensibilidade a antifúngicos de leveduras do gênero Candida isoladas da cavidade bucal de pacientes portadores do HIV. Dissertação (Mestre em Ciência da Saúde)-Faculdade de Medicina, Universidade Federal de Uberlândia,Uberlândia, Brazil, pp. 106.

8. Hani U, Shivakumar HG, Vaghela R, Osmani RA, Shrivastava A (2015) Candidiasis: a fungal infection-current challenges and progress in prevention and treatment. Infect Disord Drug Targets 15 (1): 42-52.

9. Coutinho HD (2009) Factors influencing the virulence of Candida spp. West Indian Medical Journal 58(2): 160-163.

10. Mayer FL, et al. (2013) Virulence Factors and Anti Fungal Sensitivity Pattern of Candida Sp. Isolated from HIV and TB Patients. Virulence 4 (2): 119-128.

11. Ramesh N, Priyadharsini M, Sumathi CS, Balasubramanian V, Hemapriya J, et al. (2011) Virulence Factors and Anti Fungal Sensitivity Pattern of Candida Sp. Isolated from HIV and TB Patients. Indian J Microbiol 51 (3): 273-278.

12. Fonseca GM, Passos TC, Ninahuaman MFML, Caroci AS, Costa LS (2014) Avaliação da atividade antimicrobiana do alho (Allium sativum Liliaceae) e de seu extrato aquoso. Rev Bras Pl Med 16(3): 679-684.

13. Bachir RG, Benali M (2012) Antibacterial activity of the essential oils from the leaves of Eucalyptus globulus against Escherichia coli and Staphylococcus aureus. Asian Pac J Trop Biomed 2(9): 739-742.

14. Mulyaningsih S, Sporer F, Reichling J, Wink M (2011) Antibacterial activity of essential oils from Eucalyptus and of selected components against multidrug-resistant bacterial pathogens. Pharm Biol 49(9): 893-899.

15. CLSI (2008) ( $2^{\text {nd }}$ edn) Método de referência para testes de diluição em caldo para a determinação da sensibilidade de leveduras a terapia antifúngica. Clinical and laboratorial standards institute. CLSI Norma, USA 28(14): M27-A3.

16. Gullo FP, Sardi JC, Santos VA, Sangalli-Leite F, Pitangui NS, et al (2012) Antifungal activity of Maytenin and Pristimerin. Evid Based Complement Alternat Med 2012: 340787.

17. Behbehani J, Shreaz S, Irshad M, Karched M (2017) The natural compound magnolol affects growth, biofilm formation, and ultrastructure of oral Candida isolates. Microb Pathog 113: 209-217

18. Luqman S, GR Dwivedi, MP Darokar, A Kalra, SPS Khanuja (2008) Antimicrobial activity of Eucalyptus citriodora essential oil. International Journal of Essential Oil Therapeutics 2: 69-75.

19. Taygi AK, Amit Kumar Malik, Anushree (2011) Antimicrobial potential and chemical composition of Eucalyptus globulus oil in liquid and vapour phase against food spoilage microorganisms. Food Chemistry 126(1): 228-235.

20. Harkat-Madouri L, Boudria Asma, Khodir Madani, Peggy Rigou, et al (2015) Chemical composition, antibacterial and antioxidant activities ofessential oil of Eucalyptus globulus from Algeria. Industrial Crops and Products 78: 148-153.

21. Dhakad AK, Pandey VV, Beg S, Rawat JM, Singh A (2017) Biological, medicinal and toxicological significance of Eucalyptus leaf essential oil: a review. J Sci Food Agric 98(3): 833-848.

22. Javed S, Shoaib A, Mahmood Z, Mushtaq S, Iftikhar S (2012) Analysis of phytochemical constituents of Eucalyptus citriodora L. responsible for antifungal activity against post-harvest fungi. Nat Prod Res 26(18): $1732-1736$.

23. Tolba H, H Moghrani, A Benelmouffok, D Kellou, R Maachia, et al. (2015) Essential oil of Algerian Eucalyptus citriodora: Chemical composition, antifungal activity. Journal de Mycologie Médicale 25(4): 128-133. 
This work is licensed under Creative Commons Attribution 4.0 License

DOI: 10.19080/ADOH.2018.08.555740
Your next submission with Juniper Publishers will reach you the below assets

- Quality Editorial service

- Swift Peer Review

- Reprints availability

- E-prints Service

- Manuscript Podcast for convenient understanding

- Global attainment for your research

- Manuscript accessibility in different formats ( Pdf, E-pub, Full Text, Audio)

- Unceasing customer service

Track the below URL for one-step submission https://juniperpublishers.com/online-submission.php 